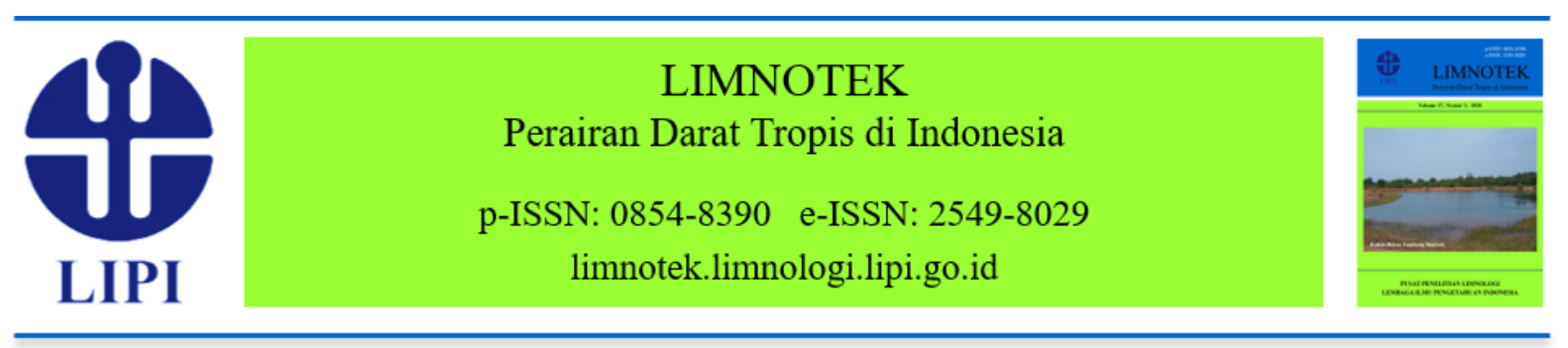

\title{
Hubungan antara Struktur Komunitas Plankton dan Tingkat Pencemaran di Situ Gunung Putri, Kabupaten Bogor
}

\author{
Thoriq Ilham ${ }^{1}$, Zahidah Hasan ${ }^{1}$, Yuli Andriani ${ }^{1}$, Heti Herawati ${ }^{1}$, \\ Fachmijany Sulawesty ${ }^{2}$ \\ ${ }^{1}$ Fakultas Perikanan dan Ilmu Kelautan, Universitas Padjadjaran \\ ${ }^{2}$ Pusat Penelitian Limnologi, Lembaga Ilmu Pengetahuan Indonesia (LIPI) \\ Email: thoriqilham@gmail.com
}

Diajukan 11 Juli 2019. Ditelaah 6 Januari 2020. Disetujui 8 Juli 2020.

\begin{abstract}
Abstrak
Situ Gunung Putri terletak di Desa Gunung Putri, Kecamatan Gunung Putri, Kabupaten Bogor. Lokasinya berada di depan pintu tol Gunung Putri. Kondisinya yang dipenuhi eceng gondok merupakan alasan situ ini dipilih sebagai objek penelitian. Tujuan penelitian ini adalah untuk menentukan tingkat pencemaran situ melalui indeks saprobitas berdasarkan komunitas plankton. Penelitian dilakukan pada Februari-Maret 2019 secara in situ di Situ Gunung Putri dan ex situ di Pusat Penelitian Limnologi LIPI di Cibinong. Metode yang digunakan adalah metode survei, berupa pengamatan dan pengukuran parameter fisika dan kimia perairan situ. Pengambilan sampel plankton menggunakan metode purposive sampling, sedangkan penghitungan plankton menggunakan metode Sedgwick Rafter. Hasil penelitian menunjukkan keanekaragaman plankton yang terdiri dari empat filum fitoplankton, yaitu Cyanophyta, Euglenophyta, Chlorophyta, dan Chrysophyta serta dua filum zooplankton, yaitu Arthropoda dan Zooflagelata. Nilai indeks keanekaragaman fitoplankton sebesar 0,6 dan zooplankton sebesar 0,7 menunjukkan bahwa kondisi lingkungan situ mampu mendukung kehidupan organisme dengan baik dan lingkungan tersebut berada dalam keadaan seimbang atau stabil yang mencirikan suatu komunitas yang stabil. Indeks dominansi fitoplankton bernilai 0,76 dan zooplankton bernilai 0,74. Nilai ini tergolong tinggi dan menunjukkan keberadaan individu yang mendominasi perairan. Fitoplankton yang mendominasi Situ Gunung Putri adalah genus Phacus sp. dari filum Euglenophyta, sedangkan zooplankton yang dominan yaitu genus Brachionus sp. dari filum Arthropoda. Indeks saprobitas selain dapat dihubungkan dengan tingkat pencemaran, juga dapat menunjukkan jenis bahan pencemar yang masuk ke perairan. Nilai indeks saprobitas yang diperoleh yaitu 0,16 termasuk ke dalam fase saprobitas $\beta / \alpha$ mesosaprobik yang mengindikasikan perairan situ mengalami pencemaran tingkat sedang dan pencemaran yang terjadi berasal dari bahan pencemar organik dan anorganik.
\end{abstract}

Kata kunci: keanekaragaman, pencemaran, plankton, saprobitas, Situ Gunung Putri 


\begin{abstract}
Relationship between Plankton Community Structure and Pollution Level in Gunung Putri Pond, Bogor Regency. Gunung Putri Pond is located in Gunung Putri Village, of Bogor Regency. Its location is in front of the Gunung Putri toll gate. Its current condition, overgrown by water hyacinth, is the reason it was chosen as the research object. The purpose of this study was to determine the level of water pollution through the saprobity index in Gunung Putri Pond based on the plankton community. The research was conducted from February to March 2019 in Gunung Putri Pond and at the Research Center for Limnology, Indonesian Institute of Sciences in Cibinong. The method used is a survey method, in the form of observation and measurement of physics and chemical parameters of the water. Plankton samples were taken using a purposive sampling method in accordance with the research objectives, while the plankton was counted using the Sedgwick Rafter method. The results of the study indicated plankton diversity consisting of four phytoplankton phyla: Cyanophyta, Euglenophyta, Chlorophyta, and Chrysophyta as well as two zooplankton phyla: Arthropoda and Zooflagellata. The phytoplankton diversity index value of 0.6 and zooplankton of 0.7 indicated that the environmental conditions were able to well support the life of organisms and the environment was in a balanced or stable state which characterized a stable community. The phytoplankton dominance index was 0.76 and zooplankton dominance index was 0.74 . These high dominance index values indicated the presence of individuals who dominated the waters. The phytoplankton that dominated Gunung Putri Pond was the genus Phacus sp. from the phylum Euglenophyta, while the dominant zooplankton was the genus Brachionus sp. from the phylum Arthropoda. The saprobity index can be related to the level of pollution, and can also indicate the types of pollutants entering the water. The obtained value of saprobity index is 0.16 which is included in the $\beta / \alpha$ mesosaprobic phase. This indicates that Gunung Putri Pond waters are experiencing moderate levels of pollution and the pollution that occurs comes from organic and inorganic pollutants.
\end{abstract}

Keywords: diversity, pollution, plankton, saprobic, Gunung Putri Pond

\section{Pendahuluan}

Keberadaan organisme di perairan dapat dijadikan sebagai indikator biologi kualitas perairan, selain indikator fisika maupun kimia. Indikator biologi tersebut dapat mengontrol kondisi perairan secara kontinu dan merupakan petunjuk yang mudah untuk mengetahui tingkat pencemaran suatu perairan. Hal ini disebabkan pencemaran yang terjadi karena pembuangan limbah di suatu perairan akan menurunkan keanekaragaman dan keseragaman hayati di lokasi perairan yang terkena dampak pembuangan limbah tersebut (Syafrudin, 2004).

Keberadaan fitoplankton di suatu perairan dapat memberikan informasi mengenai kondisi perairan tersebut secara umum. Kondisi suatu perairan yang subur dapat diindikasikan berdasarkan kelimpahan dan komposisi fitoplankton. Beberapa penelitian menggunakan indeks ekologi fitoplankton sebagai bioindikator pencemaran perairan (Gao \& Song, 2005; Spellerberg, 1993). Beberapa penelitian yang lain melihat keterkaitan antara kondisi lingkungan perairan dan distribusi (jenis dan kelimpahan) fitoplankton (Mujiyanto et al., 2011; Soedibjo, 2006; Garno, 2005).

Situ Gunung Putri terletak di Desa Gunung Putri, Kecamatan Gunung Putri, Kabupaten Bogor, Provinsi Jawa Barat. Lokasinya berada di sisi jalan tol Jagorawi di antara kawasan industri. Situ Gunung Putri memiliki luas sekitar 19 ha dengan kedalaman 1-2 m (Badan Pusat Statistik Kabupaten Bogor, 2018). Situ Gunung Putri 
sempat dijadikan objek wisata air dari tahun 2010 hingga 2013. Namun, sejak tahun 2014 objek wisata air tersebut sudah ditiadakan, sehingga situ dimanfaatkan oleh masyarakat dari sekitar situ dan luar kota untuk kegiatan memancing.

Kondisi Situ Gunung Putri yang berada di dekat permukiman tidak berbeda jauh dari situ-situ lain yang juga terletak di dekat permukiman di Kabupaten Bogor. Misalnya, Soliha et al. (2016) menunjukkan bahwa kondisi Situ Cikaret diduga telah mengalami pencemaran akibat kemasukan beban pencemar yang berasal dari limbah rumah tangga dan pembuangan sampah oleh pengunjung Situ Cikaret. Kondisi perairan Situ Gunung Putri diduga juga sudah mengalami pencemaran akibat aktivitas industri dan rumah tangga yang secara tidak langsung berdampak terhadap perubahan kondisi situ. Hal ini terutama terlihat dari permukaan air situ yang sudah ditumbuhi eceng gondok. Oleh karena itu, penelitian ini bertujuan untuk menentukan tingkat pencemaran perairan Situ Gunung Putri melalui indeks saprobitas berdasarkan komunitas fitoplankton dan zooplankton.

\section{Bahan dan Metode}

Penelitian dilaksanakan dari bulan Februari hingga Maret 2019 secara in situ di
Situ Gunung Putri dan secara ex situ di Pusat Penelitian Limnologi, Lembaga Ilmu Pengetahuan Indonesia di Cibinong. Secara in situ, stasiun pengambilan sampel plankton ditentukan dengan metode purposive sampling. Pengambilan sampel dilakukan di lima stasiun (Gambar 1), yaitu Stasiun 1 merupakan inlet yang berasal dari aktivitas industri dinamo dan industri spare part kendaraan, Stasiun 2 merupakan inlet yang berasal dari kawasan permukiman, Stasiun 3 merupakan bagian tengah Situ Gunung Putri, Stasiun 4 merupakan tempat masukan air dari kawasan pertanian ekstensif, dan Stasiun 5 merupakan outlet Situ Gunung Putri.

Pengambilan sampel air dilakukan sebanyak enam kali dengan jeda satu pekan untuk memperoleh perubahan atau suksesi fitoplankton. Sampel air diambil sebanyak 5 L menggunakan gayung ukur dari permukaan air dan kedalaman Secchi disk, kemudian disaring menggunakan net plankton no. 25 yang telah dilengkapi botol penampung bervolume $15 \mathrm{~mL}$ di bagian bawahnya. Lokasi pengambilan sampel plankton bersamaan dengan lokasi pengambilan sampel kualitas air berupa parameter fisika (suhu dan transparansi). Penghitungan plankton meliputi kelimpahan, dominansi, keanekaragaman, keseragaman, dan saprobitas.

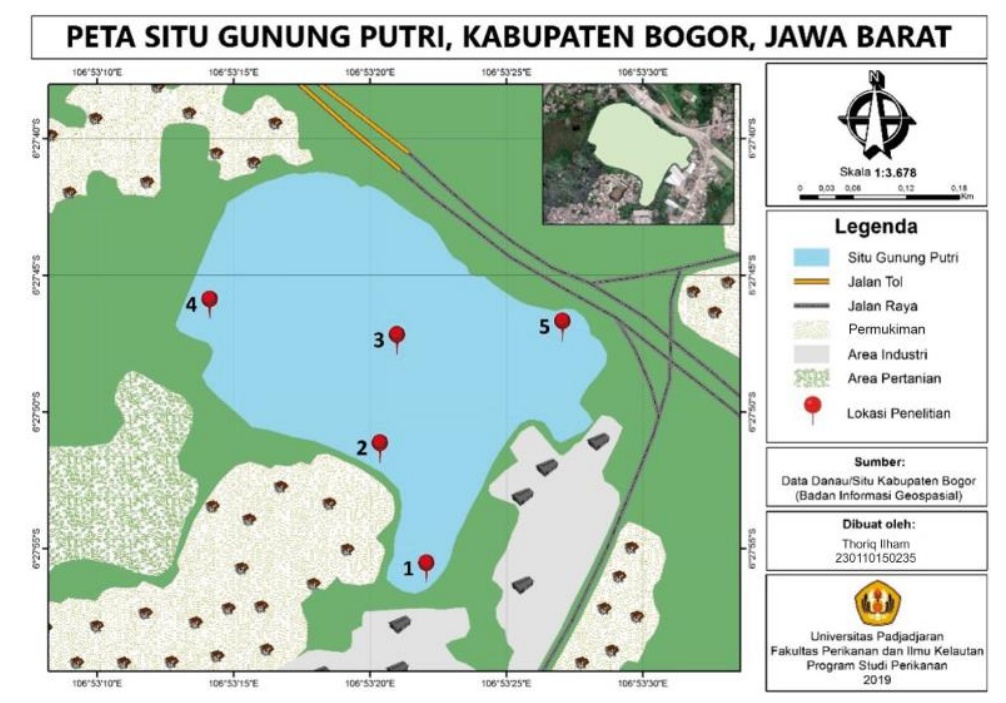

Gambar 1. Lokasi pengambilan sampel di Situ Gunung Putri 
Indeks saprobitas perairan diukur menggunakan genus fitoplankton yang ditemukan karena setiap genus fitoplankton merupakan penyusun dari kelompok saprobik tertentu yang akan memengaruhi nilai saprobitas (Indrayani et al., 2014). Tiap genus organisme saprobik akan menempati bagian perairan tertentu dan keberadaannya ditentukan oleh kualitas perairan, yaitu sifat fisika dan kimia perairan (Pringgosaputro, 1993).

Plankton diidentifikasi di bawah mikroskop Olympus CW 43 pada perbesaran $40 \times$ dan inverted microscope Nikon Diaphot 300 pada perbesaran 100×, 200x, dan 400x. Identifikasi dilakukan sampai tingkat genus berdasarkan buku identifikasi Mizuno (1979), Edmondson (1963), dan Scott \& Prescott (1961). Plankton dihitung menggunakan metode Sedgwick Rafter (APHA, 2015). Pengulangan pengambilan sampel dari setiap stasiun dan pengulangan penghitungan sampel fitoplankton dan zooplankton dilakukan sebanyak tiga kali.

Kelimpahan plankton dinyatakan secara kuantitatif dalam jumlah individu/L. Kelimpahan plankton dihitung berdasarkan rumus Fachrul (2008), yaitu:

$$
\mathrm{N}=\mathrm{n} \times \frac{\mathrm{Vr}}{\mathrm{Vo}} \times \frac{1}{\mathrm{Vs}}
$$

Keterangan:

$\mathrm{N}=$ kelimpahan plankton (individu/L)

$\mathrm{n}=$ jumlah plankton yang teridentifikasi

$\mathrm{Vr}=$ volume air yang tersaring dalam botol sampel (mL)

Vo $=$ volume air yang dihitung di atas gelas objek (mL)

Vs $=$ volume air yang disaring $(\mathrm{L})$

Indeks dominansi dihitung untuk melihat keberadaan dominansi oleh jenis plankton tertentu dalam populasi plankton di perairan. Nilai indeks dominansi berkisar $0-1$. Semakin mendekati nilai 1 berarti ada individu yang dominan di perairan tersebut. Indeks dominansi dihitung berdasarkan rumus Odum (1998), yaitu:

$$
\mathrm{D}=\sum_{\mathrm{i}=1}^{\mathrm{s}}\left(\frac{\mathrm{ni}}{\mathrm{N}}\right)^{2}
$$

Keterangan:

D = indeks dominansi Simpson

ni = jumlah individu ke-i

$\mathrm{N}=$ jumlah total individu

Indeks keanekaragaman mencerminkan jumlah jenis (spesies) yang berbedabeda dalam suatu komunitas. Apabila jumlah anggota dengan jenis yang berbedabeda banyak dalam suatu komunitas, maka komunitas tersebut memiliki keanekaragaman jenis yang tinggi. Sebaliknya, komunitas yang memiliki keanekaragaman jenis rendah hanya terdiri atas organisme tertentu dengan jumlah yang berlimpah (Soegianto, 2004). Indeks keanekaragaman Simpson menurut Odum (1998) dirumuskan sebagai berikut:

$$
\mathrm{D}=1-\left(\frac{\sum \mathrm{n}(\mathrm{n}-1)}{\mathrm{N}(\mathrm{N}-1)}\right)
$$

Keterangan:

D = indeks keanekaragaman Simpson

$\mathrm{n}=$ jumlah individu genus ke-i

$\mathrm{N}=$ jumlah total individu

Penghitungan indeks keanekaragaman menghasilkan kategori keanekaragaman dengan nilai:

D $0,0 \leq$ D $<0,4$ : keanekaragaman rendah

$0,4 \leq \mathrm{D} \leq 0,6 \quad$ : keanekaragaman sedang

$0,6<\mathrm{D} \leq 1,0 \quad$ : keanekaragaman tinggi

Indeks keseragaman dihitung untuk mengetahui keseimbangan komunitas, yaitu ukuran keseragaman jumlah individu antarspesies dalam suatu komunitas. Semakin mirip atau seragam jumlah individu antarspesies, yang berarti penyebarannya semakin merata, maka semakin besar derajat keseimbangannya. Indeks keseragaman menurut Odum (1998) dihitung berdasarkan rumus berikut: 


$$
\mathrm{E}=\frac{\mathrm{H}^{\prime}}{\mathrm{H}^{\prime} \max } \text { dengan } \mathrm{H}^{\prime} \max =\ln \mathrm{S}
$$

Keterangan:

$\mathrm{E} \quad=$ indeks keseragaman

H' = indeks keanekaragaman

H'max = keanekaragaman maksimum

$\mathrm{S} \quad=$ jumlah seluruh genus

Nilai indeks keseragaman berkisar dari 0 sampai 1. Nilai indeks keseragaman yang semakin kecil (mendekati nol) menunjukkan bahwa penyebaran jumlah individu dari setiap jenis tidak sama. Sebaliknya, jika nilai indeks keseragaman semakin besar (mendekati 1), maka populasi akan menunjukkan keseragaman dengan kisaran sebagai berikut:

$\mathrm{E}<0,4 \quad$ : keseragaman jenis rendah $0,4 \leq \mathrm{E} \leq 0,6 \quad$ : keseragaman jenis sedang $\mathrm{E}>0,6 \quad$ : keseragaman jenis tinggi

Indeks saprobitas digunakan untuk mengetahui nilai saprobitas perairan melalui analisis trosap. Indeks saprobitas ini akan menggambarkan besar beban pencemar yang terjadi dalam ekosistem di wilayah studi. Indeks saprobitas dihitung menggunakan rumus Anggoro (1988):

$$
\text { IS }=\frac{1 C+3 D-1 B-3 A}{1 A+1 B+1 C+1 D}
$$

Keterangan:

IS = indeks saprobitas

$\mathrm{A}=$ jumlah spesies organisme polisaprobik

$\mathrm{B}=$ jumlah spesies organisme $\alpha$-mesosaprobik

$\mathrm{C}=$ jumlah spesies organisme $\beta$-mesosaprobik

$\mathrm{D}=$ jumlah spesies organisme oligosaprobik

Polisaprobik adalah fase perombakan (dekomposisi) bahan-bahan organik. Fase polisaprobik dilakukan oleh banyak jasad renik. Fase $\alpha$-mesosaprobik adalah fase saprobik yang berlangsung pada tahap awal. Fase $\beta$-mesosaprobik adalah fase saprobik yang berlangsung pada tahap lanjut oleh kelompok Ciliata. Fase oligosaprobik adalah fase yang dilakukan oleh beberapa jasad renik (Sagala, 2011)

Nilai indeks saprobitas berkaitan erat dengan tingkat pencemaran perairan (Sagala, 2011). Interpretasi indeks saprobitas terhadap masing-masing tingkat pencemaran dijelaskan dalam Tabel 1 . Menurut Basmi (2000), berdasarkan organisme penyusunnya, pada umumnya tingkat saprobitas dapat dikelompokkan menjadi empat bagian (Tabel 2).

Tabel 1. Hubungan antara indeks saprobitas dan tingkat pencemaran

\begin{tabular}{cllc}
\hline Pencemar & \multicolumn{1}{c}{ Tingkat pencemaran } & \multicolumn{1}{c}{ Tingkat saprobitas } & Indeks saprobitas \\
\hline \multirow{3}{*}{ Bahan organik } & Sangat berat & Polisaprobik & $-3,0$ s.d. $-2,0$ \\
\cline { 2 - 4 } & \multirow{2}{*}{ Cukup berat } & $\begin{array}{l}\text { Poli/ } \alpha \text {-mesosaprobik } \\
\alpha \text {-meso/polisaprobik }\end{array}$ & $-2,0$ s.d. $-1,5$ \\
& & $\alpha$-mesosaprobik & $-1,5$ s.d. $-1,0$ \\
\hline \multirow{2}{*}{$\begin{array}{c}\text { Bahan organik } \\
\text { dan anorganik }\end{array}$} & \multirow{2}{*}{ Sedang } & $\alpha / \beta$-mesosaprobik & $-0,5$ \\
\cline { 2 - 4 } & \multirow{2}{*}{ Ringan } & $\beta / \alpha$-mesosaprobik & 0,0 s.d. 0,0 \\
\hline Bahan organik & \multirow{2}{*}{ Sangat ringan } & B-mesosaprobik & 0,5 s.d. 1,0 \\
dan anorganik & \multirow{2}{*}{ B-meso/polisaprobik } & 1,0 s.d. 1,5 \\
\hline
\end{tabular}


Tabel 2. Organisme penyusun tingkat saprobitas

\begin{tabular}{|c|c|c|c|c|}
\hline \multirow{2}{*}{ Kelompok saprobitas } & \multicolumn{4}{|c|}{ Organisme penyusun } \\
\hline & \multicolumn{4}{|c|}{ Ciliata } \\
\hline \multirow[t]{3}{*}{ Polisaprobik (A) } & 1. Epistylis sp. & 3. Vorticella sp. & 5. Cyclodonella sp. & 7. Ciliata $\mathrm{sp}$. \\
\hline & 2. Bursaridium sp. & 4. Favella sp. & 6. Tetrahymena sp. & 8. Coleps sp. \\
\hline & \multicolumn{4}{|c|}{ Euglenophyta } \\
\hline \multirow[t]{2}{*}{$\alpha$-Mesosaprobik (B) } & $\begin{array}{l}\text { 1. Euglena } \mathrm{sp} . \\
\text { 2. Calalium } \mathrm{sp} .\end{array}$ & 3. Phacus sp. & 4. Trachellomonas sp. & 5. Peranema sp. \\
\hline & \multicolumn{2}{|c|}{ Chlorococcales } & \multicolumn{2}{|c|}{ Diatomae } \\
\hline \multirow[t]{19}{*}{$\beta$-Mesosaprobik (C) } & 1. Cheracium $\mathrm{sp}$. & 12. Dispora sp. & 1. Coscinodisus sp. & 20. Cocconeis sp. \\
\hline & 2. Chlorococcum $\mathrm{sp}$. & 13. Tetradesmus sp. & 2. Melosira $\mathrm{sp}$. & 21. Amphipleura sp. \\
\hline & 3. Chroderia sp. & 14. Actinastrum sp. & 3. Cyclotella sp. & 22. Anomaloneis sp. \\
\hline & 4. Ankistrodesmus sp. & 15. Tetrastrum sp. & 4. Biddulphia sp. & 23. Caloneis sp. \\
\hline & 5. Chlorella sp. & 16. Microcystis sp. & 5. Hydrocera sp. & 24. Diploneis sp. \\
\hline & 6. Coelastrum $\mathrm{sp}$. & 17. Chroococcus sp. & 6. Triceratium $\mathrm{sp}$. & 25. Frustuila sp. \\
\hline & 7. Scenedesmus sp. & 18. Aphanocapsa sp. & 7. Caetoceros sp. & 26. Gyrosigma sp. \\
\hline & 8. Pediastrum sp. & 19. Merismopedia sp. & 8. Rhizozolenia sp. & 27. Navicula sp. \\
\hline & 9. Tetraedron sp. & 20. Polycystis sp. & 9. Diatomae sp. & 28. Neridium sp. \\
\hline & 10. Pediastrum simplex & 21. Coelosphaerium sp. & 10. Asterionella sp. & 29. Pinnularia sp. \\
\hline & 11. Pediastrum duplex & & 11. Ceratoneis sp. & 30. Pleurosigma sp. \\
\hline & & & 12. Fragilaria sp. & 31. Rhopalodia sp. \\
\hline & & & 13. Synedra sp. & 32. Bacillaria sp. \\
\hline & & & 14. Tabellaria sp. & 33. Cilindroteae $\mathrm{sp}$. \\
\hline & & & 15. Achnanthes sp. & 34. Nitzschia sp. \\
\hline & & & 16. Stephanodiscus sp. & 35. Campylodiscus sp. \\
\hline & & & 17. Fragilaria capucina & 36. Surirella sp. \\
\hline & & & $\begin{array}{l}\text { 18. Climacosphenia moniligera } \\
\text { 19. Cymbella } \mathrm{sp} \text {. }\end{array}$ & 37. Planktoniella sp. \\
\hline & \multicolumn{2}{|c|}{ Peridiniidae } & \multicolumn{2}{|c|}{ Conjugales } \\
\hline Oligosaprobik (D) & 1. Peridinium $\mathrm{sp}$. & 2. Ceratium $\mathrm{sp}$. & 1. Mougeotia sp. & 7. Closterium sp. \\
\hline & & & 2. Mougeotiopsis sp. & 8. Cosmarium sp. \\
\hline & & & 3. Spirogyra sp. & 9. Desmidium $\mathrm{sp}$. \\
\hline & & & 4. Zygnema sp. & 10. Dolidium sp. \\
\hline & & & 5. Zygogonium sp. & 11. Arthrodesmus sp. \\
\hline & & & 6. Bambusina sp. & 12. Cylindrocystis $\mathrm{sp}$. \\
\hline
\end{tabular}




\section{Hasil}

Fitoplankton yang ditemukan di Situ Gunung Putri terdiri dari empat filum dan 25 genus, sedangkan zooplankton terdiri dari dua filum dan 11 genus. Filum dan genus plankton yang teridentifikasi diperlihatkan dalam Tabel 3.

Keberadaan fitoplankton pada setiap pengamatan didominasi oleh filum Euglenophyta dengan kepadatan rata-rata tertinggi terdapat di Stasiun 5 (outlet) seba-

Tabel 3. Kepadatan plankton yang diidentifikasi (individu/L) di Situ Gunung Putri

\begin{tabular}{|c|c|c|c|}
\hline Plankton & Filum & Genus & Kepadatan \\
\hline \multirow[t]{25}{*}{ Fitoplankton } & \multirow{7}{*}{ Cyanophyta } & Aphanocapsa & 11 \\
\hline & & Chroococcus & 1.718 \\
\hline & & Gleocapsa & 297 \\
\hline & & Merismopedia & 25 \\
\hline & & Oscillatoria & 443 \\
\hline & & Phormidium & 1 \\
\hline & & Spirulina & 1.370 \\
\hline & \multirow{3}{*}{ Euglenophyta } & Euglena & 2.162 \\
\hline & & Phacus & 12.829 \\
\hline & & Trachellomonas & 31 \\
\hline & \multirow[t]{14}{*}{ Chlorophyta } & Actinastrum & 124 \\
\hline & & Ankistrodesmus & 76 \\
\hline & & Chlorella & 4 \\
\hline & & Chlorococcum & 20 \\
\hline & & Coelastrum & 117 \\
\hline & & Crucigenia & 9 \\
\hline & & Dictyosphaerium & 171 \\
\hline & & Pandorina & 47 \\
\hline & & Pediastrum & 291 \\
\hline & & Scenedesmus & 608 \\
\hline & & Selenastrum & 6 \\
\hline & & Staurastrum & 15 \\
\hline & & Tetraedron & 41 \\
\hline & & Westella & 8 \\
\hline & Chrysophyta & Navicula & 31 \\
\hline \multirow[t]{11}{*}{ Zooplankton } & Zooflagellata & Trepomonas & 14 \\
\hline & \multirow[t]{10}{*}{ Arthropoda } & Cyclops & 57 \\
\hline & & Nauplius & 38 \\
\hline & & Thermocyclops & 42 \\
\hline & & Anuraeopsis & 4 \\
\hline & & Brachionus & 209 \\
\hline & & Proales & 3 \\
\hline & & Filinia & 2 \\
\hline & & Cladocera sp1. & 4 \\
\hline & & Daphnia & 2 \\
\hline & & Moina & 4 \\
\hline
\end{tabular}


nyak 4.914 individu/L (Gambar 2). Hal ini terjadi karena titik outlet merupakan tempat akumulasi aliran air yang akan keluar dari berbagai area situ, sehingga bahan-bahan organik banyak terkumpul di stasiun tersebut. Chrysophyta merupakan filum dengan kepadatan individu terendah, yaitu enam individu/L dari enam kali pengamatan dengan hanya satu genus yang ditemukan, yaitu Navicula.

Kepadatan total rata-rata zooplankton di perairan Situ Gunung Putri diperlihatkan dalam Gambar 3, sedangkan dinamika kepadatan fitoplankton dan zooplankton diperlihatkan dalam Gambar 4 dan 5.

Hasil penghitungan nilai indeks kea- nekaragaman, keseragaman, dominansi, dan saprobitas fitoplankton diperlihatkan dalam Tabel 5. Indeks keanekaragaman fitoplankton terendah 0,38 ditemukan di Stasiun 4, sedangkan indeks keanekaragaman tertinggi 0,86 ditemukan di Stasiun 1. Indeks keseragaman terendah 0,13 ditemukan di Stasiun 4, sedangkan indeks keseragaman tertinggi 0,28 ditemukan di Stasiun 1. Indeks dominansi terendah 0,38 ditemukan di Stasiun 1, sedangkan indeks dominansi tertinggi 0,97 terdapat di Stasiun 4. Indeks saprobitas terendah 0,10 ditemukan di Stasiun 4, sedangkan indeks saprobitas tertinggi dengan nilai 0,22 terdapat di Stasiun 2.

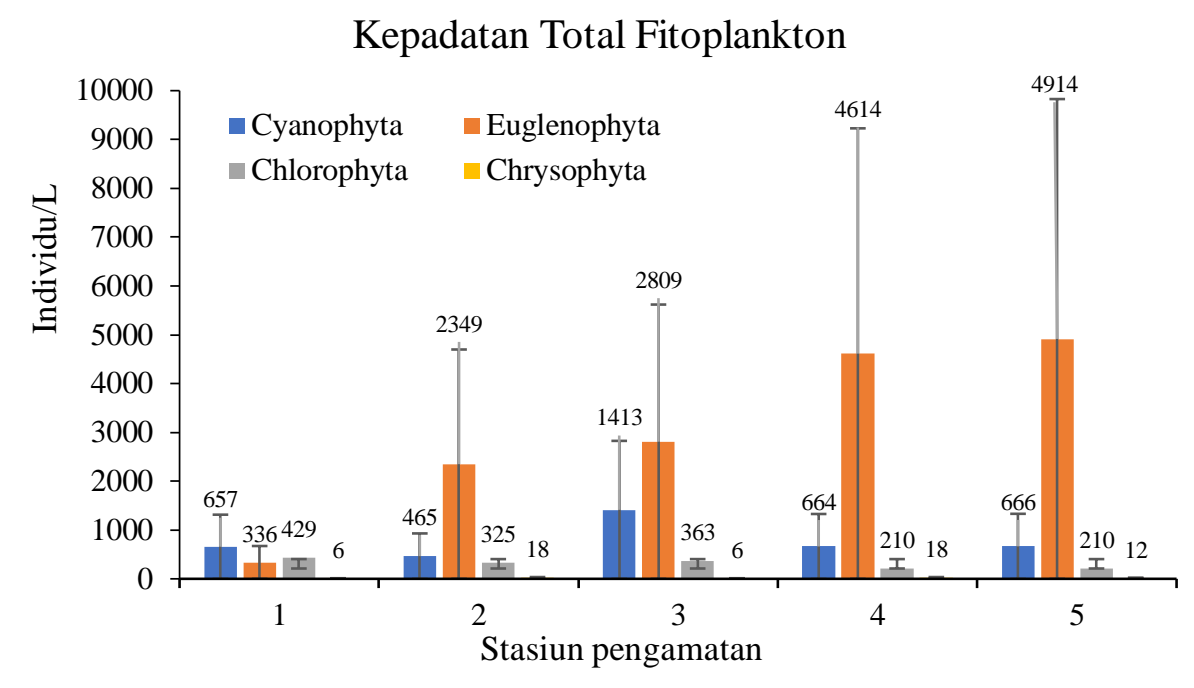

Gambar 2. Kepadatan total rata-rata fitoplankton di perairan Situ Gunung Putri

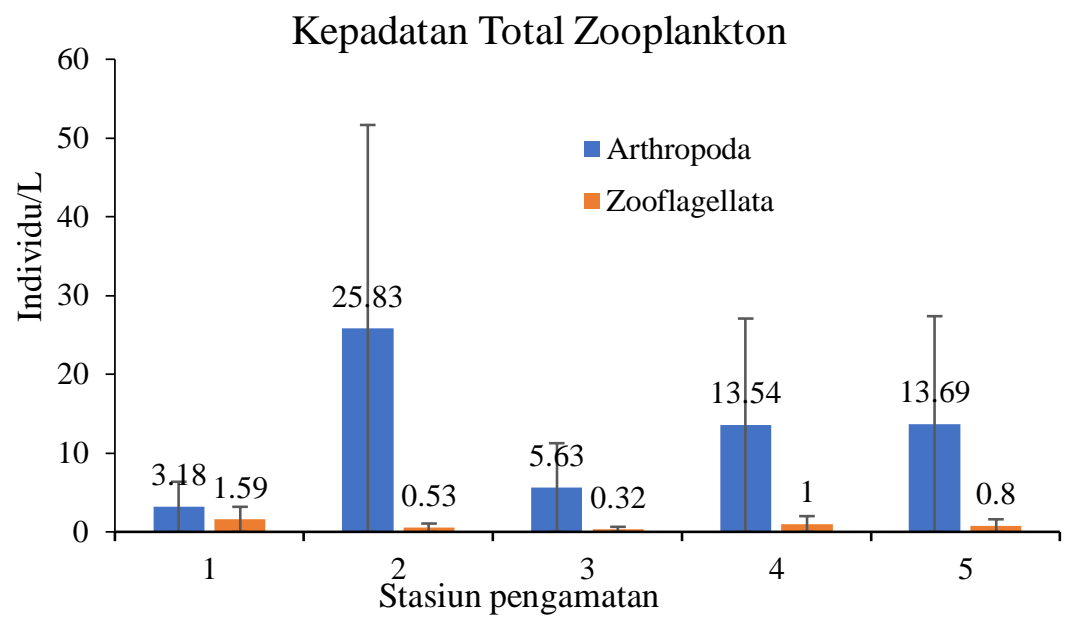

Gambar 3. Kepadatan total rata-rata zooplankton di perairan Situ Gunung Putri 


\section{Dinamika Kepadatan Fitoplankton}

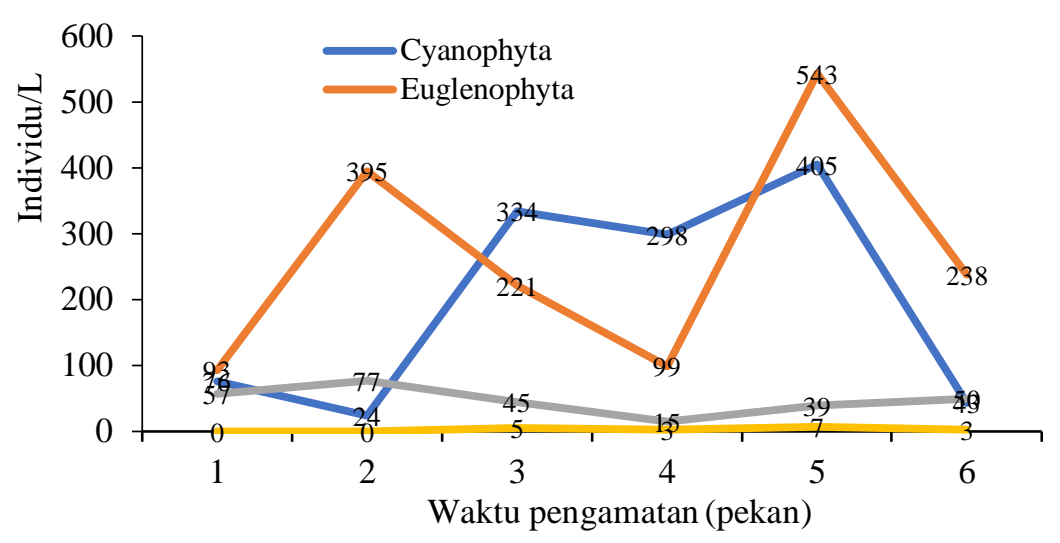

Gambar 4. Dinamika kepadatan fitoplankton di perairan Situ Gunung Putri

Dinamika Kepadatan Zooplankton

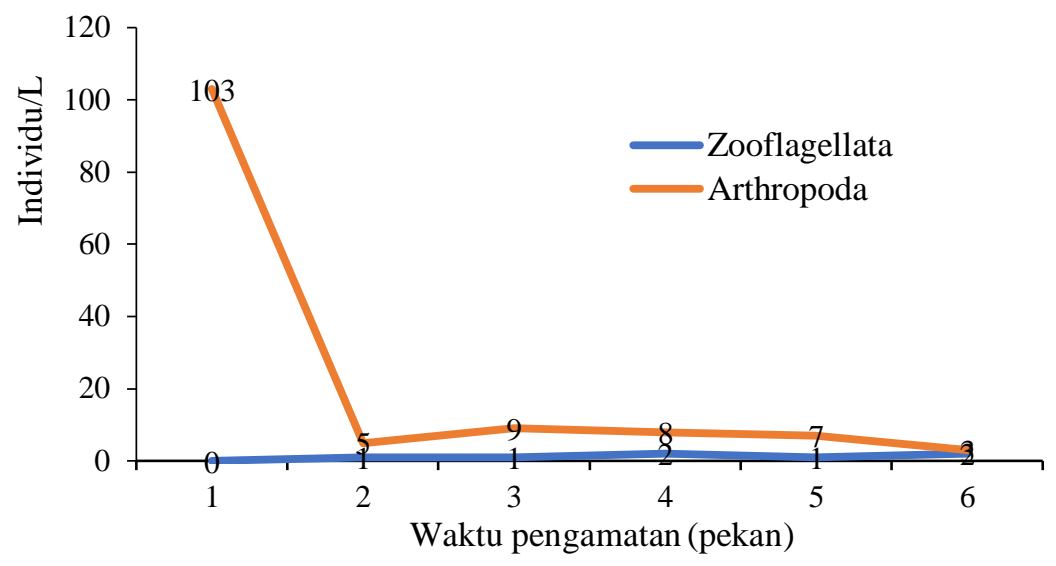

Gambar 5. Dinamika kepadatan zooplankton di perairan Situ Gunung Putri

Tabel 5. Nilai rata-rata indeks keanekaragaman, keseragaman, dominansi, dan saprobitas fitoplankton

\begin{tabular}{lcccccc}
\hline \multirow{2}{*}{ Indeks } & \multicolumn{7}{c}{ Stasiun } \\
\cline { 2 - 7 } & 1 & 2 & 3 & 4 & 5 & Rata-rata \\
\hline Keanekaragaman (H') & 0,86 & 0,59 & 0,70 & 0,38 & 0,49 & 0,60 \\
Keseragaman (E) & 0,28 & 0,19 & 0,23 & 0,13 & 0,18 & 0,20 \\
Dominansi (D) & 0,38 & 0,92 & 0,62 & 0,97 & 0,89 & 0,76 \\
Saprobitas (IS) & 0,18 & 0,22 & 0,18 & 0,10 & 0,13 & 0,16 \\
\hline
\end{tabular}

\section{Pembahasan}

Penelitian ini menemukan genera fitoplankton predominan yang sama dengan hasil penelitian Soliha et al. (2016) di Situ Cikaret, yaitu Phacus, Euglena, dan Trachellomonas. Nannavecchia et al. (2014) dalam penelitiannya di Sungai 
Matanza, Buenos Aires, Argentina, banyak menemukan Phacus brachykentron di perairan dengan kandungan bahan organik tinggi karena sifat Phacus (Euglenophyta) yang sensitif dengan kandungan bahan organik yang kaya. Dalam penelitian ini, kepadatan total rata-rata Phacus yang mencapai 12.829 individu/L jauh lebih banyak dibandingkan genus lain dalam filum Euglenophyta, seperti Euglena sebanyak 2.162 individu/L dan Trachellomonas yang hanya berjumlah 31 individu/L. Dominansi Phacus sebagai indikator bahan organik yang tinggi didukung oleh penelitian Aristawidya et al. (2020) yang menyebutkan bahwa pencemaran di Situ Gunung Putri disebabkan aktivitas antropogenik dari kawasan permukiman, aktivitas pertanian, dan aktivitas industri berupa pengayaan unsur hara dari bahan organik.

Ramirez dan Bicudo (2005) menjelaskan bahwa Navicula merupakan fitoplankton yang digunakan sebagai indikator konsentrasi nitrat yang tinggi. Hal ini sesuai dengan keadaan di Situ Gunung Putri, yaitu konsentrasi nitrat selama pengamatan yang sangat rendah, berkisar 0,04-0,06 mg/L (Hasan et al., 2019) mengakibatkan kelimpahan Navicula yang juga rendah.

Pada pengamatan pekan pertama dan kedua, fitoplankton predominan adalah Phacus dari filum Euglenophyta sebanyak 93 dan 395 individu/L (Gambar 4). Pada pekan ketiga dan keempat, filum predominan adalah Cyanophyta dari genus Spirulina sebanyak 334 individu/L dan Chroococcus sebanyak 298 individu/L. Selanjutnya, pada pekan kelima dan keenam, Phacus dari filum Euglenophyta kembali mendominasi sebanyak 543 dan 238 individu/L. William dan Lewis (1978) menyatakan bahwa suksesi merupakan perubahan kelimpahan relatif spesies dalam suatu komunitas yang terjadi secara episodik. Suksesi fitoplankton disebabkan oleh perubahan kondisi fisika, kimia, dan biologi perairan, seperti disebutkan oleh Meisiana et al. (2020), bahwa suksesi fitoplankton di Danau Garden House dipengaruhi oleh faktor fisika, kimia, dan biologi seperti $\mathrm{pH}$, salinitas, konduktivitas, amonium, nitrit, nitrat, ortofosfat, dan zooplankton.

Komposisi zooplankton lebih sedikit dibandingkan fitoplankton. Hal ini merupakan kondisi alami perairan karena zooplankton berada pada tingkat trofik kedua yang memakan fitoplankton dan sekaligus merupakan sumber energi (makanan) bagi krustasea pada tingkat ketiga. Faktor lain yang menyebabkan populasi zooplankton yang rendah yaitu keberadaan ikan-ikan karnivora dan omnivora yang hidup di perairan (Hasan $e t$ al., 2013). Hal ini sesuai dengan kondisi yang ada bahwa di perairan Situ Gunung Putri terdapat ikan-ikan karnivora seperti ikan Gabus dan ikan Toman, serta ikan omnivora seperti ikan Mas.

Genus terbanyak yang ditemukan dari filum Arthropoda yaitu Brachionus dari ordo Rotifera. Hal ini dikarenakan Brachionus memiliki toleransi hidup yang tinggi pada berbagai kondisi perairan. Selain itu, Anggraini et al. (2016) menyatakan bahwa kelimpahan Rotifera yang tinggi di suatu perairan menandakan perairan tersebut mengandung banyak bahan organik sebagai sumber makanannya. Menurut Landner (1978), perairan dengan kelimpahan fitoplankton yang berkisar 2-2.000 individu/L tergolong perairan oligotrofik dengan kesuburan rendah. Adapun perairan dengan kelimpahan fitoplankton 2.000-15.000 individu/L tergolong perairan mesotrofik dengan tingkat kesuburan sedang. Kepadatan fitoplankton dalam penelitian ini berkisar 2-20.484 individu/L (Gambar 2), sehingga Situ Gunung Putri tergolong perairan oligotrofik hingga mesotrofik dengan tingkat kesuburan rendah hingga sedang.

Dominasi zooplankton dari filum Arthropoda di perairan Situ Gunung Putri merupakan hal yang umum. Hal ini sesuai dengan penelitian Zulfiandi, et al. (2014) yang menyatakan bahwa zooplankton di 
suatu ekosistem perairan sebagian besar didominasi oleh filum Arthropoda, yaitu sebanyak 70-90\%. Selain itu, predominansi pada zooplankton tidak memperlihatkan perbedaan suksesi yang signifikan (Gambar 5). Filum Arthropoda selalu dominan dari pekan pertama hingga keenam. Pada pekan pertama dan kedua, Brachionus predominan sebanyak 103 dan 5 individu/L. Pada pekan ketiga, Cyclops yang predominan dengan kepadatan 9 individu/L. Pada pekan keempat, Brachionus kembali mendominasi perairan dengan kepadatan 8 individu/L. Pada pekan kelima dan keenam, Cyclops yang kembali predominan dengan kepadatan 7 dan 3 individu/L.

Nilai indeks keanekaragaman fitoplankton tertinggi 0,86 yang ditemukan di Stasiun 1 menunjukkan bahwa Stasiun 1 memiliki komunitas yang stabil, sedangkan indeks keanekaragaman stasiun lain yang lebih rendah tergolong dalam kategori sedang. Nilai indeks keseragaman fitoplankton pada penelitian ini yang berkisar 0,13-0,28 dan rata-rata 0,20 (Tabel 5) hampir serupa dengan hasil penelitian Maresi et al. (2015) di Situ Bulakan, Kota Tangerang yang memiliki variasi indeks keseragaman 0,17-0,29 dengan rata-rata 0,21 . Secara umum, dari setiap stasiun pengamatan nilai indeks keseragaman yang diperoleh kurang dari 0,4. Hal ini mengindikasikan bahwa keseragaman jenisnya rendah akibat persebaran individu tiap jenis yang tidak merata atau ada salah satu jenis yang mendominasi komunitas, sehingga keseimbangan ekosistem menjadi rendah. Semakin kecil nilai indeks keseragaman dalam suatu komunitas berarti penyebaran individu tiap spesies atau genus tidak merata dan ada kecenderungan suatu komunitas untuk didominasi oleh spesies atau genus tertentu (Odum, 1998). Distribusi fitoplankton secara horizontal banyak dipengaruhi oleh faktor fisika seperti pergerakan massa air dan faktor kimia seperti $\mathrm{pH}$ dan DO, serta kandungan nutrien. Faktor fisika dan kimia itulah yang menyebabkan distribusi horizontal fitoplankton tidak merata dan kelimpahan fitoplankton yang berbeda (Wulandari et al., 2014).

Indeks dominansi yang tinggi menunjukkan ada genus yang dominan dalam perairan. Indeks dominansi dalam penelitian ini berkisar 0,38-0,97 dengan rata-rata 0,76 (Tabel 5). Nilai indeks keanekaragaman yang rendah $(0,38)$ dan nilai indeks dominansi yang mendekati angka 1 di Stasiun 4 menandakan keberadaan individu yang dominan, yaitu Phacus. Berdasarkan indeks dominansi Simpson, yaitu jika nilai indeks dominansi $0<\mathrm{D} \leq 0,5$ maka tidak ada genus yang dominan, namun jika nilai indeks dominansi $0,5<\mathrm{D} \leq 1$ maka terdapat genus yang mendominasi suatu komunitas. Secara umum, nilai indeks dominansi rata-rata 0,76 menunjukkan keberadaan individu yang dominan di semua stasiun pengamatan.

Nilai-nilai indeks dalam penelitian ini hampir serupa dengan nilai-nilai indeks penelitian Soliha et al. (2016) di Situ Cikaret, yaitu nilai indeks dominansi berkisar 0,01-0,97, nilai indeks keanekaragaman berkisar $0,03-0,15$, dan nilai indeks keseragaman berkisar 0,009-0,014. Hal ini menunjukkan kemiripan kondisi kedua perairan karena sama-sama terletak di dekat wilayah permukiman dengan beban masukan limbah yang sejenis.

Indeks saprobitas tertinggi dengan nilai 0,22 berasal dari Stasiun 2, yaitu inlet dari kawasan permukiman yang membawa limbah organik dan anorganik, sehingga perairan situ tercemar oleh limbah antropogenik yang memengaruhi nilai indeks saprobitas. Menurut Fachrul et al. (2005) tingkat saprobitas dipengaruhi kuat oleh kedekatan badan air dengan permukiman penduduk, sedimentasi, dan bahan pencemar organik maupun anorganik yang masuk ke perairan. Secara umum, nilai indeks saprobitas di Situ Gunung Putri yang berkisar dari 0,10 sampai 0,22 menyebabkan perairan ini tergolong kategori $\beta / \alpha$-mesosaprobik dengan beban bahan pencemar organik dan anorganik, 
serta termasuk ke dalam tingkat pencemaran sedang karena berada dalam rentang 0,0-0,5 (Suwondo \& Dessy, 2004).

\section{Kesimpulan}

Dengan tingkat keanekaragaman sedang, kondisi lingkungan Situ Gunung Putri masih mampu mendukung kehidupan fitoplankton cukup baik dan berada dalam keadaan seimbang atau stabil yang mencirikan suatu komunitas yang stabil. Dominansi genus Phacus terjadi di hampir semua stasiun pengamatan dan indeks saprobitas menunjukkan bahwa masukan beban pencemar berupa limbah organik dan anorganik mengindikasikan perairan mengalami pencemaran tingkat sedang dan tergolong pada fase saprobitas $\beta / \alpha$ mesosaprobik. Pada umumnya, kondisi perairan Situ Gunung Putri ini hampir serupa dengan kondisi situ-situ lain yang berada di dekat kawasan permukiman dengan beban masukan berupa limbah organik.

\section{Ucapan Terima Kasih}

Ucapan terima kasih kami sampaikan kepada Pusat Penelitian Limnologi LIPI dan Fakultas Perikanan dan Ilmu Kelautan Universitas Padjadjaran yang telah memberikan dukungan dalam kegiatan riset ini.

\section{Referensi}

Anggoro S. 1988. Analisis TropikSaprobik (TROSAP) untuk Menilai Kelayakan Lokasi Budidaya Laut. Makalah Workshop Budidaya Laut Perguruan Tinggi Se-Jawa Tengah, 6690

Anggraini A, Sudarsono, Sukiya. 2016. Kelimpahan dan Tingkat Kesuburan Plankton di Perairan Sungai Bedog. Jurnal Biologi 5(6): 1-9
APHA. 2015. Standard Methods for the Examination of Water and Wastewater. 21st edition. American Public Health Association, American Water Works Association, Water Pollution Control Federation. Washington DC

Aristawidya M, Hasan Z, Iskandar, Yustiawati, Herawati H. 2020. Status Pencemaran Situ Gunung Putri di Kabupaten Bogor Berdasarkan Metode STORET dan Indeks Pencemaran. LIMNOTEK Perairan Darat Tropis di Indonesia 27(1): 27-38

Badan Pusat Statistik Kabupaten Bogor. 2018. Kecamatan Gunung Putri Dalam Angka 2018. BPS Kabupaten Bogor

Basmi HJ. 2000. Planktonologi: Plankton sebagai Bioindikator Kualitas Perairan. Fakultas Perikanan dan Ilmu Kelautan Institut Pertanian Bogor. Bogor

Edmondson WT. 1963. Fresh Water Biology. Second Edition. John Wiley \& Sons, Inc., New York

Fachrul MF. 2008. Metode Sampling Bioekologi. PT. Bumi Aksara. Jakarta

Fachrul MF, Haeruman H, Sitepu LC. 2005. Komunitas Fitoplankton sebagai Bioindikator Kualitas Perairan Teluk Jakarta. Seminar Nasional MIPA. Fakultas Arsitektur Lansekap Teknologi Lingkungan. Universitas Trisakti. Jakarta, 17-24

Gao X, Song J. 2005. Phytoplankton Distribution and Their Relationship with the Environment in the Changjiang Estuary, China. Marine Pollution Bulletin 50: 327-335

Garno YS. 2005. Kajian Status Kualitas Perairan Jangari Cirata dan Kelayakannya untuk Daerah Wisata Air. Jurnal Teknologi Lingkungan 6: 416423

Hasan Z, Syawalludin IN, Lili W. 2013. Struktur Komunitas Plankton di Situ Cisanti Kabupaten Bandung, Jawa Barat. Jurnal Akuatika 4(1): 80-88

Hasan Z, Ilham T, Andriani Y, Herawati H, Sulawesty F. 2019. Water Quality Distribution in Situ Gunung Putri Bogor Regency, Indonesia. Asian Journal of 
Fisheries and Aquatic Research 4(3):18

Indrayani N, Anggoro S, Suryanto A. 2014. Indeks Trofik-Saprobik sebagai Indikator Kualitas Air di Bendung Kembang Kempis Wedung, Kabupaten Demak. Diponegoro Journal of Maquares Management of Aquatic Resources 3(4):161-168

Kementerian Lingkungan Hidup. 2014. Profil, Strategi, dan Rencana Aksi Pelestarian Situ di Jabodetabek. Jakarta Landner. 1978. Eutrophication of Lakes. Analysis Water and Air Pollution Research Laboratory Stockholm. Sweden

Meisiana S, Pratiwi NTM, Ayu IP. 2020. Keterkaitan Suksesi Fitoplankton dengan Kualitas Air di Danau Garden House, Pantai Indah Kapuk, Jakarta Utara. Prosiding Pertemuan Ilmiah Tahunan Ke-1V MLI 2019, 97-112

Mizuno T. 1979. Ilustrations of the Freshwater Plankton of Japan. Hoikusha Publishing Co. Ltd., Osaka

Mujiyanto, Tjahjo DWH, Sugianti Y. 2011. Hubungan antara Kelimpahan Fitoplankton dengan Konsentrasi N:P pada Daerah Karamba Jaring Apung (KJA) di Waduk Ir. H. Djuanda. LIMNOTEK Perairan Darat Tropis di Indonesia 18(1): 15-25

Nannavecchi P, Tolivia A, Conforti V. 2014. Ultrastructural Alteration in Phacus brachynkentron (Euglenophyta) Due To Excess of Organic Matter in the Culture Medium. Ecotoxicology and Environmental Safety 101: 36-41

Odum EP. 1998. Dasar-Dasar Ekologi. Edisi Ketiga Diterjemahkan oleh Tjahjono Samingan. Gadjah Mada University Press. Yogyakarta

Ramirez J, Bicudo CEM. 2005. Diurnal and Spatial (Vertical) Dynamics of Nutrient (N, P, Si) in Four Sampling Days (Summer, Fall, Winter and Spring) in A Tropical Shallow Reservoir and Their Relationships With The Phytoplankton Community. Brazilian Journal of Biology 65(1): 141-157
Peraturan Pemerintah Republik Indonesia. Pengelolaan Kualitas Air dan Pengendalian Pencemaran Air Nomor 82 Tahun 2001

Pringgosaputro S. 1993. Studi Keterkaitan antara Pembuangan Limbah Industri dengan Tingkat Saprobitas di Muara Sungai Sambong Kab. Dati II Batang (Sebagai upaya pendugaan Tingkat Pencemaran). Laporan penelitian. PPLH Lembaga Penelitian Universitas Diponegoro, Semarang

Sagala EP. 2011. Indeks Saprobik Komunitas dalam menentukan Tingkat Pencemaran di Perairan Laut antara Muara Sungai Benu dan Pulau Betet, Kabupaten Banyuasin, Provinsi Sumatra Selatan. Maspari Journal 02: 11-18

Scott AM, Prescott GW. 1961. Indonesian Desmids. Hydrobiologia 17: 1-132

Soedibjo BS. 2006. Struktur Komunitas Fitoplankton dan Hubungannya dengan Beberapa Parameter Lingkungan di Perairan Teluk Jakarta. Oseanologi dan Limnologi di Indonesia 40: 65-78

Soegianto A. 2004. Metode Pendugaan Pencemaran Perairan Dengan Indikator Biologis. Surabaya. Airlangga University Press

Soliha E, Rahayu SSY, Triastinurmiatiningsih. 2016. Kualitas Air dan Keanekaragaman Plankton di Danau Cikaret, Cibinong, Bogor. Ekologia 16(2): $1-10$

Spellerberg IF. 1993. Monitoring Ecological Change. Cambridge University Press New York, USA

Suwondo EF, Dessy AM. 2004. Kualitas Biologi Perairan Sungai Senapelan, Sago, dan Sail di Kota Pekanbaru Berdasarkan Bioindikator Plankton dan Bentos. Biogenesis 1(1): 15-20

Syafrudin. 2004. Pengelolaan Sampah Berbasis Masyarakat. Prosiding Diskusi Interaktif Pengelolaan Sampah Terpadu. Program Magister Lingkungan Universitas Diponegoro. Semarang

Wulandari DY, Pratiwi NTM, Adiwilaga EM. 2014. Distribusi Spasial Fitoplankton di Perairan Pesisir 
Tangerang. Jurnal Ilmu Pertanian Indonesia 19(3): 156-162

William M, Lewis JR. 1978. Analysis of Succession in A Tropical Phytoplankton Community and a New Measure of Succession Rate. The American Naturalist 112: 984

Zulfiandi, Zainuri M, Widowati I. 2014. Kajian Distribusi/Sebaran Fitoplankton dan Zooplankton di Perairan dan Estuaria Banjir Kanal Barat Kota Semarang Jawa Tengah. Prosiding Seminar Kelautan Nasional IX, 24-31 